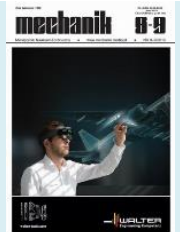

Title of article: „Metodyka oceny topografii czynnej powierzchni ściernic w aspekcie ich potencjału obróbkowego” ("The methodology of the grinding wheel active surface evaluation in the aspect of their machining potential")

Mechanik, Vol. 91, No. 8-9 (2018): pages 690-697

DOI: https://doi.org/10.17814/mechanik.2018.8-9.108

\title{
The methodology of the grinding wheel active surface evaluation in the aspect of their machining potential
}

\author{
Metodyka oceny topografii czynnej powierzchni ściernic \\ w aspekcie ich potencjału obróbkowego
}

\author{
WOJCIECH KACALAK \\ DARIUSZ LIPIŃSKI \\ FILIP SZAFRANIEC \\ KATARZYNA TANDECKA *
}

\begin{abstract}
Estimation of the machining capacity of grinding wheels after the conditioning process, during their operation and after the grinding process is an important and complex problem. The article presents a methodology for the evaluation of wheel topography using a new height indicator and sharpness of abrasive grains, which enables determination of the machining potential of the wheel to be tested. Analysis of the developed parameter was carried for three different grinding wheels and for two different state after the conditioning process and after 30 minutes of grinding.

KEYWORDS: grinding wheel active surface, grinding wheel active surface evaluation parameters, grinding wheel active surface machining potential, grinding wheel active surface stereometric structure
\end{abstract}

The machining capacity of abrasive tools results from: the features of the tool structure, the type and properties of abrasives and their adhesives, geometrical parameters of abrasive grains and topography of the active surface [4, 7-9, $11,15]$. Different signals from the process being carried out or from the properties of the tools may be used to evaluate the processing potential. Typically, after the initial transformation of the signals, the usefulness of the measure is evaluated to assess the condition of the tool, taking into account the strength and consistency of the measure's dependence on changes in the tool state $[5,10,12,2,22,24$, 25]. The measures used can be divided into measures in the fields of time, frequency and time-frequency.

During grinding, the mechanical and chemical properties of the grinding wheel do not change greatly, while the grinding wheel's active surface changes as a result of wear processes $[2,3,27,38,39]$. Abrasion of the tips of abrasive grains (fig. 1a) contributes to the increase of forces and specific energy, crushing of the tops of grains is a process of renewing the cutting properties, and the crushing of whole grains results in deviations in the dimensions and shape of the tool. In the treatment of light metal alloys, there may also be fragmentary coverage of the active surface of grinding wheels with processing products (fig. 1b) $[4,28]$.

* Prof. dr hab. inż. Wojciech Kacalak (wk5@tu.koszalin.pl), dr inż. Dariusz Lipiński (dariusz.lipinski@tu.koszalin.pl),dr inż. Filip Szafraniec (filip.szafraniec@tu.koszalin.pl),dr inż. Katarzyna Tandecka (katarzyna. tandecka@tu.koszalin.pl) - Wydział Mechaniczny Politechniki Koszalińskiej

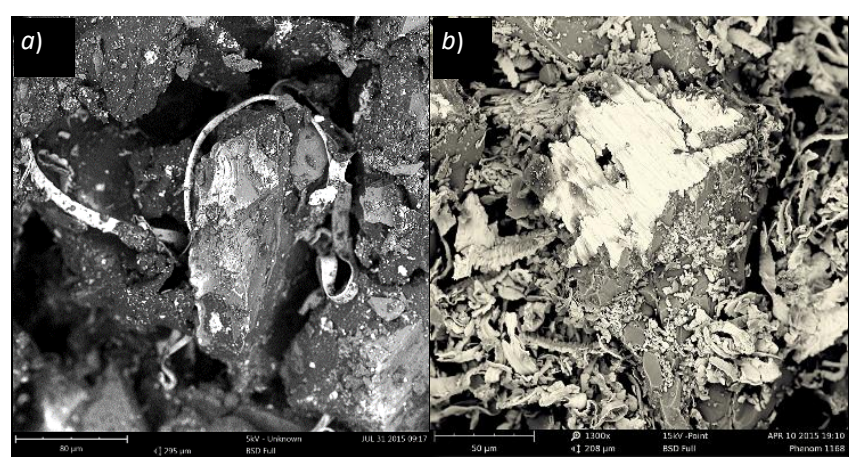

Fig. 1. Examples of wheel grinding forms: a) image of the initial phase of abrasive wear of the top of the grain, $b$ ) grinding on the surface of the grinding wheel

In formulating an effective methodology to assess the topography of the active surface of grinding wheels, in the aspect of detecting adverse changes in its condition, the following problems require solutions:

- determination of measures useful for evaluation of machining potential and identification of forms of wear $[1,3$, 5, 12-14, 18, 37];

- determination of the methodology for determining digital images of grinding wheel surfaces (preferably without disassembly from the grinder spindle - using scanning methods, light scattering analysis methods $[22,23]$ or replica methods [18]), including selection of areas to measure and taking into account the diversity of micro-screening conditions and characteristics of grain consumption in individual zones of the active surface;

- definition of tool durability criteria [7, 26, 27, 37, 39]. The basics of the selection of parameters for the assessment of the topography of grinding wheel surfaces are different from the basics of the evaluation of the geometrical structure of the treated surfaces. The differences most often result from the need to identify grains as specific spatial forms and from the need to identify forms of grinding wheel wear. In addition, the surfaces of abrasive tools and surfaces after machining with these tools differ little in terms of gradient value and unevenness structure $[13,16,37]$, thus it can be concluded that most parameters for the evaluation of stereometric features useful for assessing topography after machining are not useful for assessment of the active surface of grinding wheels. 
In each of these cases, the methodology for the selection of parameters for the assessment of stereometric features, forming a complementary set, ensuring high classification effectiveness and the ease of interpreting the assessments and technological suitability will be different.

Next, the methodology for the evaluation of the active state of abrasive tools surfaces is used, using new, effective parameters that allow for a more complete analysis of tool wear, evaluation of their condition and selection of treatment parameters, as well as determination of durability.

\section{Practical importance of the topography evaluation of the active surface of grinding wheels}

The complexity of assessing the state of the active surface of grinding wheels, carried out for the purpose of forecasting the results of the process and durability of tools, results not only from the randomness of the shape and position of abrasive grains, but also from a large number of interactions of grains and their impact on the shape of the surface.

The sizes of abrasive grains usually range from $0.5 \mu \mathrm{m}$ (abrasive foils, lapping and polishing pastes, abrasive microbrews) to $300 \mu \mathrm{m}$ (grinding wheels for efficient grinding and cutting). The number of grains in a volume of $1 \mathrm{~mm}^{3}$ varies from $3^{3}$ to $10^{6}$

The specific energy in abrasive and erosive machining processes is considerable - usually from 10 to $1000 \mathrm{~J} / \mathrm{mm}^{3}$ $[13,20]$. The temperature in micro-volumes often exceeds $1200^{\circ} \mathrm{C}$ and even $1500^{\circ} \mathrm{C}$, which results, among others, in formation of microwells in the form of spherical shells [18] with sizes from several to several dozen micrometers and a characteristic form, resulting from stresses in the coatings during cooling.

Local temperature gradients reach $10^{6} \mathrm{C} / \mathrm{s}$ and $10^{\circ} \mathrm{C} / \mathrm{mm}$. The high energy consumption of the grinding processes results in considerable forces and thermal phenomena that cause deformation of the workpiece, tool and machining system, as well as unfavorable stress distributions in the surface layer of the workpieces.

The inaccuracy of production is influenced not only by the energy consumption of processes and processing power, but also by the local concentration of energy, the shape and location of the treatment zone and the speed of the heat source [2, 3, 13, 14, 35]. It follows that the most accurate and comprehensive assessment of the properties of abrasive tools is a very important task of great practical importance.

\section{Probabilistic aspects of shaping the machined surface in grinding processes}

The phenomena occurring in the grinding zone are described by features with a short time of occurrence (about tens of microseconds), include areas with small areas of local impact (about a dozen or so square micrometers) and are characterized by a discontinuity of creating a shallow form of the removed material elements with great frequency $(0.3 \div 10$ $\mathrm{MHz}$ ). These phenomena are therefore difficult to experimentally observe.

For example, on the surface of a grinding wheel with diameter $D=400 \mathrm{~mm}$ and height $H=40 \mathrm{~mm}$ and grain size $a_{z}=120 \mu \mathrm{m}$ there are more than $2 \cdot 10^{6}$ abrasive grains, and on the surface $500 \times 20 \mathrm{~mm}$ abrasive film with diamond particles with a dimension of $0.5 \mu \mathrm{m}-$ about $10^{10}$ grains.

The characteristics of abrasive grains depend on micro-cutting processes in which there is a large variation: side flows of material and formation of flash, separation of material and its removal from the treated surface, and forces and temperature in the contact zone.

When analyzing the number of events per unit time of the grinding process, it can be noticed that for the example of a grinding wheel, when its peripheral speed is $60 \mathrm{~m} / \mathrm{s}$, the number of grains moving over the surface of the object in $1 \mathrm{~s}$ time exceeds $1.2 \cdot 10^{7}$. During processing of $120 \mathrm{~s}$, almost one and a half billion grains pass over the surface of the object. These values are many times greater for smaller grains.

The analysis of the geometrical parameters of abrasive grains and the quantities characterizing their distribution, in particular the indicators characterizing the grinding wheel machining potential, as well as the analysis of changes in these quantities during the grinding process is the basis for analyzing the phenomena occurring during machining.

These issues acquire particular importance in the grinding of new materials, often difficult to process, including light metal alloys used in the aerospace and biomedical industries $[4,6,8,15,17]$. With the increase in the use of these materials, there is a need to design and create new tools with precisely defined and controlled parameters describing the design and distribution of abrasive grains.

In precise abrasive machining, the phenomena occurring in the environment of a single abrasive blade have - due to the massive nature and complex mechanisms of the accumulation of mechanical and thermal effects $[13,14,17$, 35 ] - a decisive influence on the technological and economic parameters of the machining. Knowledge of deformations, stresses and displacements of the material processed in the micro-separation process is a source of valuable information on the phenomena occurring in the micro-scratching process. Combining this data with the evaluation of the tool's properties and the analysis of their changes along with the time of grinding, made with the use of indicators of high classification capacity, allows for the optimization of the process.

It should be emphasized that the features and sizes of active fragments of the surface of the grain tops are variable in the contact zone and depend on the grain depth, variable along the grain path [17]. Based on the analysis of the material separation mechanism and its lateral displacements, it can be concluded that orientation of the grain in relation to the main motion direction, increasing the width of the cutting layer, is one of the ways to limit unfavorable lateral material flows $[17,18]$. This applies to grains having a flat or preferably concave rake surface with a small inclination angle $\gamma$ (usually negative in abrasive microscopic processes). The corner features such as large radii of roundings or clashing of the tips as well as the staining of the tool surface with machining products are disadvantageous.

In the diagnosis of geometrical forms of unfavorable changes in topography of the active surface, it should be taken into account that clusters of top surfaces are characterized by a field much smaller than the area of the middle grain section or cross-sectional area at the height of the binder. Fields of flat areas, which are the surface overlays of the tool, are characterized by a larger development of the circumference and a field much larger than the largest even fields of grain clash.

The topography of the active surface of the grinding wheel along with the parameters of the grinding process and the properties of the technological system determines the geometrical structure of the surface being machined. This, in turn, has a big impact, among others on:

- friction processes and wear of associated surfaces,

- deformation and contact stiffness,

- concentration of stress and fatigue strength,

- resistance to corrosive effects,

- tightness of connections,

- contact thermal conductivity,

- phenomena of reflection, absorption and penetration of waves (light, electromagnetic, etc.),

- application processes, adhesion and strength of refining coatings,

- properties of textures produced in subsequent treatments,

- aerodynamic and hydrodynamic properties,

- subjective assessments of buyers of specific products. 
The surface shaping of accurate elements often occurs in abrasive or erosive machining processes. Such surfaces have randomized fractal features, sometimes with a "foreign" main component [3, 5, 13, 30, 33, 34, 36]. Knowledge about the processes of shaping the geometric structure of the surface in the grinding process is important in formulating the form of indicators used to assess the topography of the grinding wheel.

\section{Methodology of creating effective measures and parameters for the topography evaluation of the active surface of abrasive tools}

Topography of the surface of tools and workpieces is the subject of research conducted in many scientific centers [5, 33, 35, 37-39]. However, the approach still prevails, in which similar parameters are used to analyze these two different types of surfaces, making the assessment of their interaction less precise.

The aim of the authors was to determine sets of parameters: with maximum information usefulness, fulfilling the complementarity condition, containing information on the dispersion and variability of geometric parameters, facilitating the interpretation of the relationship between parameter values and specific surface features and enabling the determination of possible adjustments to the surface shaping process. It has been taken into account that the sets of parameters useful for the evaluation of abrasive tool surfaces will be different than for the evaluation of machined surfaces.

In the topography analysis of the active surface of abrasive tools, particular attention should be paid to the features of peaks of grain tops over a certain plane located at different levels, e.g. from 0.1 to 0.4 values of the St parameter from the highest surface peak (fig. 2). This is due to the features of the process in which the tool's active surface contacts the workpiece only the tops of the most protruding grains towards the surface being machined. Valuable conclusions regarding the results of the abrasive machining process can be derived, among others, thanks to decomposition of the tool surface with the use of Voronoi cells.

The first task is to determine the distance between the peaks of the hills by the method of nearest neighbors whose central points are the peaks of the grains [16]. This then allows to determine the relations between the grain base field and the Voronoi cell field, and determine the inclination angles of the lines connecting the neighboring grain peaks.

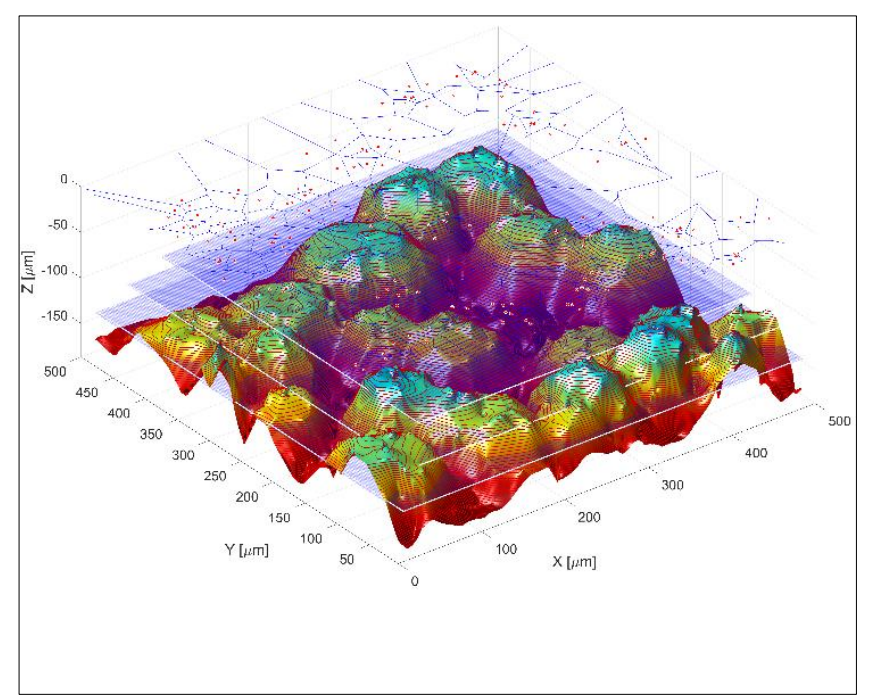

Fig. 2. Scheme for analysis of hill elevation characteristics of abrasive grains located at different levels of St value from the highest point of the grinding wheel

Evaluation of the distribution and shape of hill tops grains above a certain level from the highest peak can be, among others base for:
- grain activity evaluation;

- forecasting of the specific energy of the treatment, depending on distribution of geometrical parameters of machined layers individual grains;

- assessment of tool wear processes;

- selection of machining parameters.

The developed software allows to designate, among others the following parameters:

- sets $z(x, y)$ for surface elevations;

- surface of the elevation above the specified plane;

- surface of the base of the elevation (island);

- geometric measures of elevations;

- number of hills;

- $x$ and $y$ coordinates of the highest apex of the hill;

- height and dispersion of vertex heights altitude;

- average distance between elevation peaks, designated on the basis of cell surface decomposition Voronoi by the method of closest neighbors;

- surface area of Voronoi cells,

- $x$ and $y$ coordinates of the Voronoi cell vertices;

- relations between the field and the perimeter of the base of the hill;

- parameters characterizing the development of the base circumference exaltation;

- values and statistical characteristics of the first derivative distribution outline: $\mathrm{d} z / \mathrm{d} x, \mathrm{~d} z / \mathrm{d} y$ (including value statistics close to zero);

- variability of the described parameters in the position function cutting plane.

\section{New, effective indicator of the topography evaluation of the active surface of grinding wheels and forecasting of tool machining potential}

The measures described above for the evaluation of the active state of abrasive tool surfaces characterize important features, but their information content increases only in a carefully selected set of several measures. The measure, which decisively increases the information content, is the new parameter, which captures both the height position and the sharpness of the vertex peaks. This parameter ( $\left.W_{\text {wozs }}\right)$, which is a surface feature (3D), was developed by the authors using the applications in the AM-FM (2D) signal analysis of the Teager-Kaiser energy operator (TKEO), useful for demodulation of signals [1, 26, 31].

The TKEO operator - proposed for the first time by Teager and then refined by Kaiser [21] - captures the level and variability of the analyzed signal. The discrete TKEO value can be estimated on the basis of three neighboring signal samples $z_{i-1}, z_{i}, z_{i+1}$ (for all values of the $z$ signal, i.e. for $i=1$ ... n).

Kaiser [21] in the operator's description cites an analogy to the energy of a vibrating spring-mass system in which the total energy is proportional to the square of the mass velocity and its potential.

The TKEO operator is defined as follows:

$$
\Psi_{Z(z(x))}=(\mathrm{d} z / \mathrm{d} x)^{2}-z(x) \cdot\left(\mathrm{d}^{2} z / \mathrm{d} x^{2}\right)
$$

or a discrete form, approximate formula:

$$
\Psi z(z(i))=z(i)^{2}-z(i-1) z(i+1)
$$

In the assessment of stereometric features of the active surface of abrasive tools, the geometrical features of areas including grain tops are important, i.e. those parts of the profile that are located above a certain level $h, z_{h}=z-h>0$, e.g. above the mean line $h=0$, i.e. $z-h>0$.

It is also worth noting that in the assessment of the height and variability of elevation profiles, in the case of abrasive 
tools (due to their operational features), it is justified to determine the absolute value from $\psi_{\mathrm{z}}$.

The usefulness of $z$ index for surface evaluation, even after its modifications, is limited due to the fact that this index refers to the profile, and the inference about the surface topography of abrasive tools based on the profile is not sufficiently accurate.

Therefore, the authors developed a height and variability index of the height (sharpness) of the grain tops, referring to the surface (3D), with the following form:

$w_{\text {wozs }}(x, y)=(\operatorname{abs}(f z h(x, y)))^{0,5}$

where:

$f z h(x, y)=f z(x, y)$ dla $z(x, y)>h$

$f z(x, y)=z(x, y)^{4}-z(x-1, y) \cdot z(x+1, y) \cdot z(x, y-1) \cdot z(x, y+1)$

$W_{\text {wozs }}=\left(\Sigma W_{\text {wozs }}(x, y)\right) /\left(R_{X} \cdot R_{Y}\right)$

where: $R_{X}, R_{Y}$ is the size of the rectangular surface area in the $x$ and $y$ directions, and $W_{\text {woz }}$ is a dimensionless indicator.

\section{Research methodology}

The abrasive materials:

- A 1-250 × 25 × 76.2-99A100K7VTE10-35 - conventional grinding wheel,

- B 1-250 × $25 \times 76,2-99 A 100 K 7 I V T E 10-35$ - grinding wheel with modified spatial structure (with increased porosity),

- C 1-250 × $25 \times 76.2-99$ AY100K7VTE10-35 - grinding wheel containing special grain with spatially developed structure.

Conditions and parameters of wheel exploitation tests are summarized in tab. I.

\section{TABLE I. Conditions of grinding performance tests}

\begin{tabular}{|l|c|}
\hline Grinding speed $v_{\mathrm{s}}, \mathrm{m} / \mathrm{s}$ & 35 \\
\hline Longitudinal feed $v_{\mathrm{t}}, \mathrm{m} / \mathrm{min}$ & 25 \\
\hline Cross feed $a_{\mathrm{p}}, \mathrm{mm} / \mathrm{skok}$ & 0.5 \\
\hline Wheel alignment $a_{\mathrm{e}}, \mu \mathrm{m}$ & 100 \\
\hline Conditioning alignment $a_{\mathrm{d}}, \mathrm{mm}$ & $0.1-0.15$ \\
\hline Workpiece material & X153CrMoV12 (NC11LV) \\
\hline
\end{tabular}
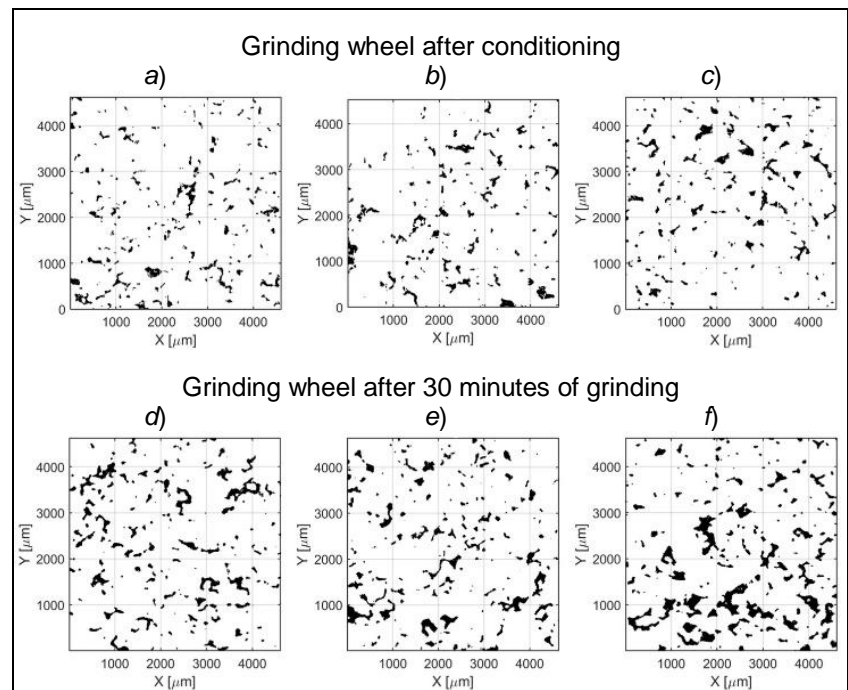

Fig. 3. View of flat areas for conventional grinding wheel $(a, d)$ induced $(b, e)$ and spatially developed grain structure $(c, f)-$ after conditioning and after 30 minutes of grinding, respectively
The research of topography of abrasive tools was carried out by the method of replication of the active surface, using material for RepliSet replicas by Struers (according to the manufacturer, the resolution of this material is $0.1 \mu \mathrm{m}$ ). Measurements of tool surfaces after conditioning and after the machining process (after 20 passes and after $30 \mathrm{~min}$ ) were made using Olympus LEXT OLS4000 measurement system.

Images of flat areas on the surface of the tested grinding wheels (fig. 3) were determined taking into account two criteria: the value of the first derivative of the height of grain surface elevations above the level of the adhesive and the height of specific points of these elevations. The boundary condition for the first criterion was: $d z /(d x \cdot d y)<\left(0.3 \cdot(d z)_{\text {sr }}\right)$, with the average value of the $d z$ derivative being about 12 times lower than the maximum value. The limit condition for the second criterion was: $z>0.7 \cdot \max (z)$.

\section{Evaluation of the active surface condition of abrasive tools}

Fig. 4 presents the determined values of the $W_{\text {wozs }}$ index $(x, y)$ for the tested grinding wheels after the process of shaping their active surface and after grinding with the parameters given in the tab. I.

There are significant differences in the local values of this indicator for the new active surface and the area changed as a result of wear after 30 minutes of grinding - this applies to all three tested wheels. First of all, the maximum value of the indicator decreases more than twice, which means high sensitivity of this parameter, especially that the values of typical surface topography evaluation parameters, determined in order to compare suitability, change rather little or their changes are not a result of wear. The analysis shows that the average of $25 \%$ of maximum values, preferably on a surface containing not less than 1000 grains, can be a good parameter of the consumption dynamics evaluation.

Fig. 5 shows grain contour views - the contours of the highest sharp edges are highlighted in red. There is a very large decrease in the value of the $W_{\text {wozs }}$ index (sharpness of the highest vertices).

Clear differences in the $W_{\text {wozs }}$ index value can be seen in histograms (fig. 6), especially for wheels with induced porosity (fig. 6c and fig. 6d) and larger distances between active grains, which means their higher load and lower specific energy of grinding. Similarly, for grinding wheels with a developed surface (fig. 6e and fig. 6f), the initial values of the indicator were smaller compared to the remaining grinding wheels, which resulted from the leveling of the peaks after the process of shaping the grinding wheel surface; after grinding, there was a significant reduction in the size of large index values. This means that many new small microwells were created at a similar height, and the number of vertices located high above the active surface decreased (which is confirmed by data in tab. III).

Tab. II lists the more important parameters used to assess the stereometric features of the surface, and in the table III average values of the developed indicator along with selected other values of known parameters for the assessment of stereometric features of the surface for the three tested grinding wheels in the two analyzed states.

The average value of the $W_{\text {wozs }}$ index for grinding wheels containing grains with developed surface increased after grinding, thus the surface condition of the grinding wheel did not deteriorate, on the contrary - many new aligned tips of abrasive grains appeared. The values of some parameters, e.g. $S_{p q}$ and $S_{b i}$, differentiate the grinding wheel parameters before and after grinding, but they are not correlated with changes in cutting properties, which depend on the sharpness of the abrasive grains with the largest radii of action. 


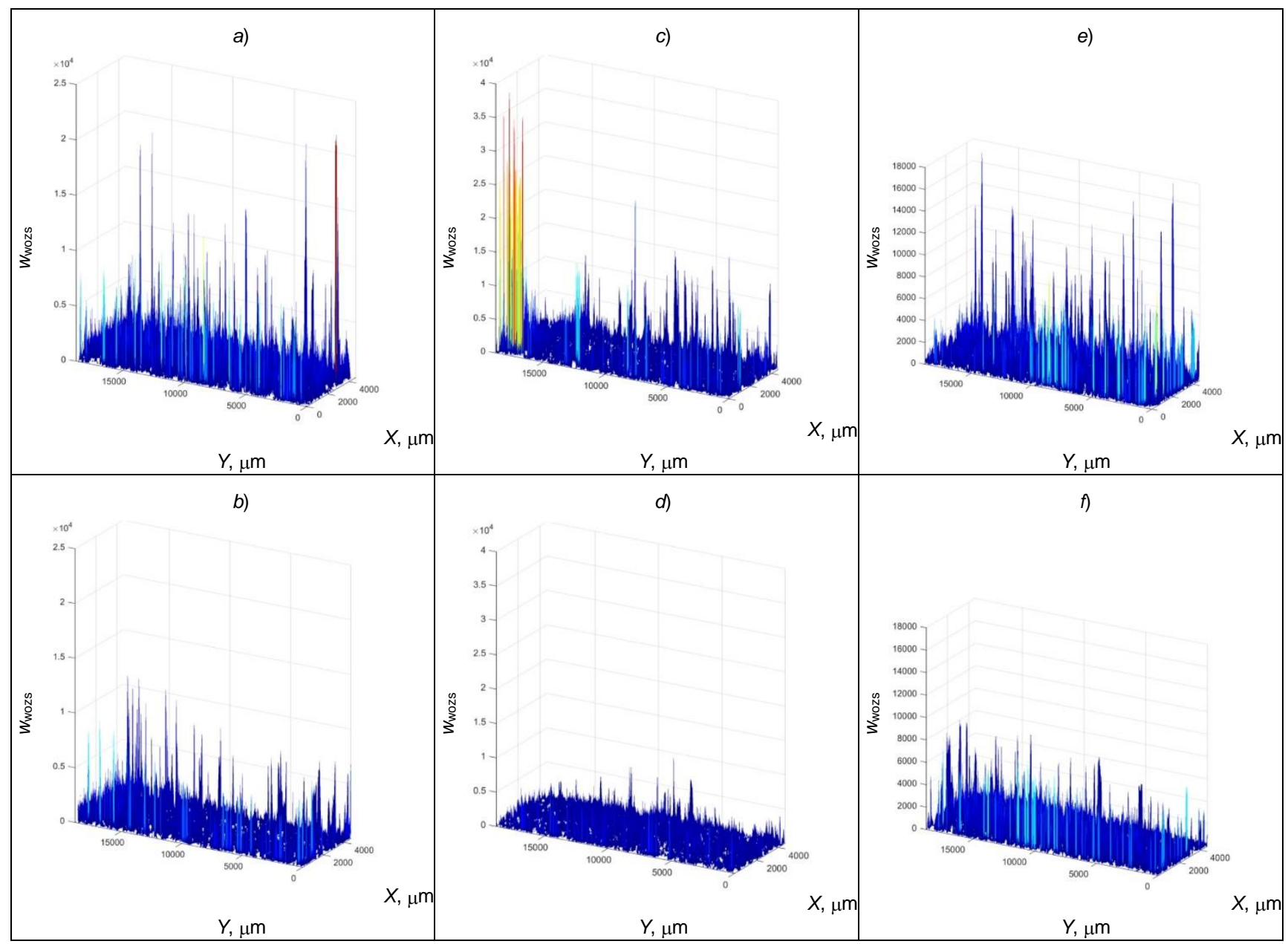

Fig. 4. Local values of the $W_{\text {wozs }}$ index $(x, y)$ for grinding wheel after conditioning: a) conventional, $c$ ) with induced porosity, e) with spatially developed grain structure, and grinding wheel after 30 min grinding: $b$ ) conventional, $d$ ) o induced porosity, $f$ ) with spatially developed grain structure

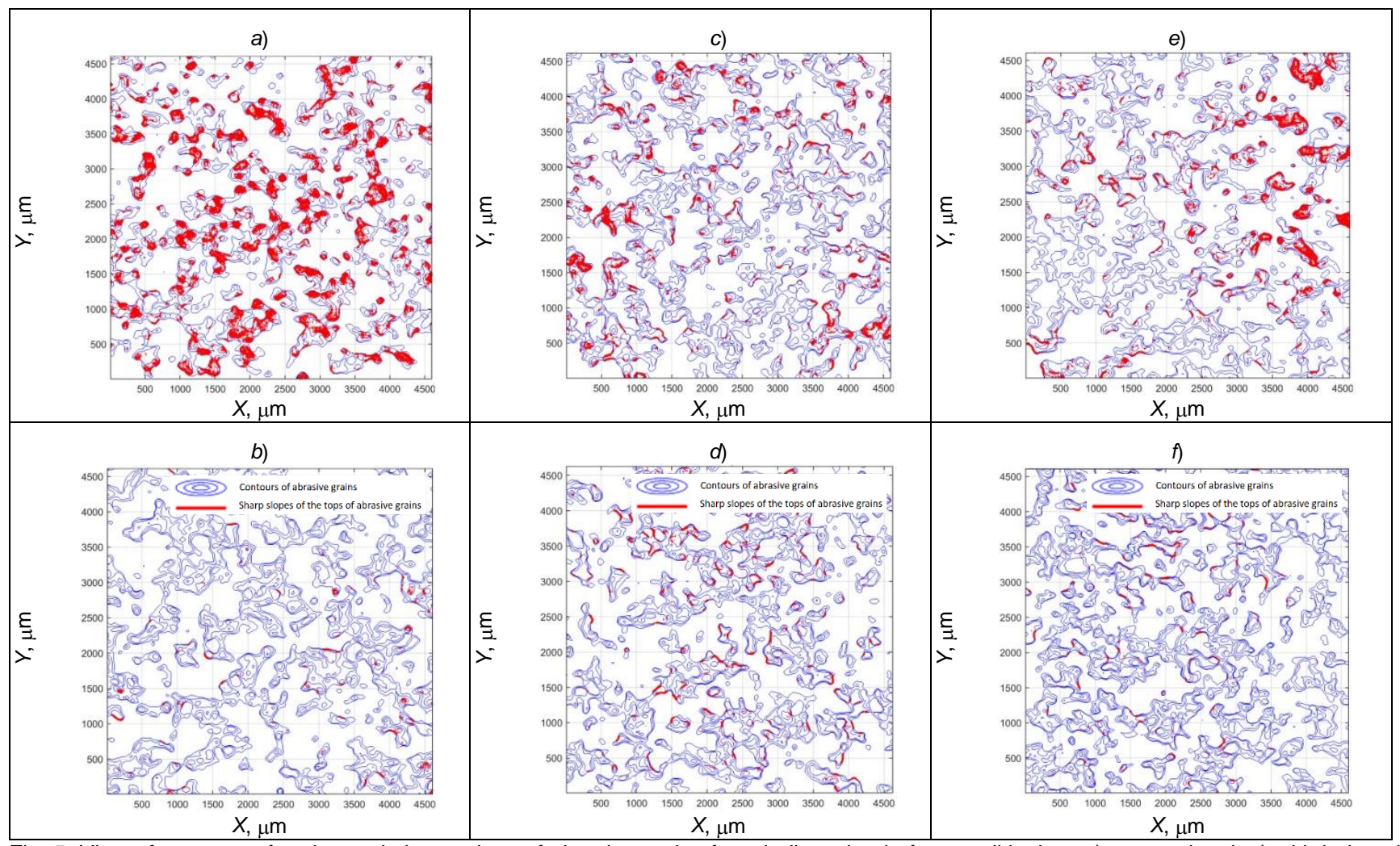

Fig. 5. View of contours of grains and sharp edges of abrasive grains for grinding wheel after conditioning: a) conventional, $c$ ) with induced porosity, $e$ ) with spatially developed grain structure, and grinding wheel after 30 minutes of grinding: $b$ ) conventional, $d$ ) with induced porosity, f) with spatially developed grain structure 


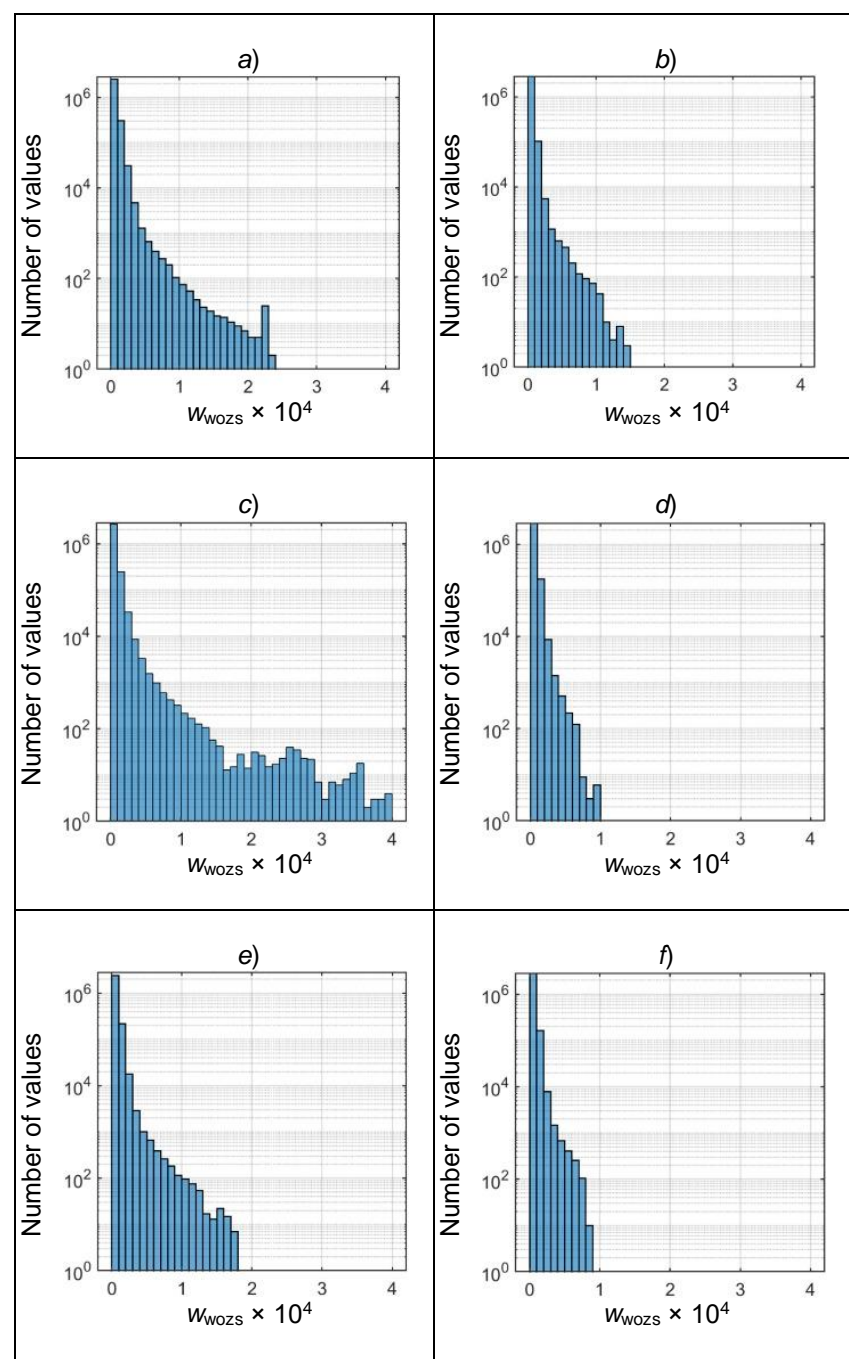

Fig. 6. Histogram of local values of the $W_{\text {wozs }}$ index $(x, y)$ for a grinding wheel after conditioning: a) conventional, $c$ ) with induced porosity, $e$ ) with spatially developed grain structure, and grinding wheel after 30 min grinding: b) conventional, d) with induced porosity, f) with spatially developed grain structure

TABLE II. Set of the most important parameters for the evaluation of stereometric features of the surface

\begin{tabular}{|c|c|c|}
\hline Parameter & Context & Description \\
\hline$W_{\text {wozs }}$ & $\begin{array}{c}h=0 \\
h=0.5 \cdot S p\end{array}$ & $\begin{array}{l}\text { height and sharpness indicator } \\
\text { of abrasive grains }\end{array}$ \\
\hline$S q, \mu \mathrm{m}$ & & mean square surface deviation \\
\hline Sku & & kurtosis (excess) of the surface \\
\hline$S p, \mu m$ & & maximum height of the hill \\
\hline$S v, \mu \mathrm{m}$ & & maximum depth of the recess \\
\hline $\mathrm{Sa}, \mu \mathrm{m}$ & & average arithmetic deviation \\
\hline$S m c, \mu \mathrm{m}$ & $p=10 \%$ & inverse area surface material ratio \\
\hline$S x p, \mu \mathrm{m}$ & $\begin{array}{c}p=50 \% \\
q=97.5 \%\end{array}$ & extreme height of the summit \\
\hline$S d q$ & & mean square surface gradient \\
\hline$S d r, \%$ & & $\begin{array}{c}\text { coefficient of surface area } \\
\text { development }\end{array}$ \\
\hline$S p d, 1 / \mu m^{2}$ & \multirow{4}{*}{ trimming $=5 \%$} & density of surface peaks \\
\hline$S p c, 1 / \mu \mathrm{m}$ & & $\begin{array}{l}\text { arithmetic mean curvature } \\
\text { of the surface peak }\end{array}$ \\
\hline$S d a, \mu m^{2}$ & & average valley area \\
\hline Sha, $\mu \mathrm{m}^{2}$ & & area of the average hill \\
\hline$S t, \mu \mathrm{m}$ & & total height \\
\hline$S d s, 1 / \mu m^{2}$ & & vertex density \\
\hline$S s c, 1 / \mu \mathrm{m}$ & & $\begin{array}{l}\text { arithmetic mean curvature } \\
\text { of the vertex }\end{array}$ \\
\hline Spq & $\begin{array}{c}\text { Gaussian filter, } \\
0.8 \mathrm{~mm}\end{array}$ & $\begin{array}{c}\text { mean square unevenness } \\
\text { of the plateau }\end{array}$ \\
\hline Svq & $\begin{array}{c}\text { Gaussian filter, } \\
0.8 \mathrm{~mm} \\
\end{array}$ & $\begin{array}{l}\text { mean square unevenness } \\
\text { of the valley }\end{array}$ \\
\hline Smq & $\begin{array}{c}\text { Gaussian filter, } \\
0.8 \mathrm{~mm}\end{array}$ & $\begin{array}{c}\text { material ratio on the plateau-valley } \\
\text { transition }\end{array}$ \\
\hline Sbi & & $\begin{array}{c}\text { indicator of the material surface } \\
\text { area }\end{array}$ \\
\hline
\end{tabular}

TABLE III. Determined values of selected parameters for the evaluation of stereometric features of the surface of the tested grinding wheels

\begin{tabular}{|l|c|c|c|c|c|c|}
\hline $\begin{array}{l}\text { Type of grinding } \\
\text { wheel }\end{array}$ & \multicolumn{2}{|c|}{ A } & \multicolumn{2}{c|}{$\mathrm{B}$} & \multicolumn{2}{c|}{ C } \\
\hline $\begin{array}{l}\text { Grinding time, } \\
\text { min }\end{array}$ & 0 & 30 & 0 & 30 & 0 & 30 \\
\hline$W_{\text {wozs }}$ & 14.3 & 9.66 & 14.1 & 11.9 & 12.0 & 13.3 \\
\hline Sq, $\mu \mathrm{m}$ & 63.2 & 56.4 & 67.2 & 65.4 & 62.8 & 64.8 \\
\hline Sku & 3.3 & 4.49 & 5.94 & 7.84 & 4.84 & 4.07 \\
\hline Sp, $\mu \mathrm{m}$ & 159 & 119 & 232 & 120 & 144 & 107 \\
\hline Sv, $\mu \mathrm{m}$ & 317 & 356 & 472 & 599 & 484 & 398 \\
\hline Sa, $\mu \mathrm{m}$ & 51 & 43.8 & 51.5 & 49.7 & 49.2 & 51.4 \\
\hline Smc, $\mu \mathrm{m}$ & 76.1 & 63.5 & 74 & 72.9 & 72.8 & 73.7 \\
\hline Sxp, $\mu \mathrm{m}$ & 148 & 146 & 165 & 164 & 155 & 165 \\
\hline Sdq & 1.63 & 1.32 & 1.64 & 1.5 & 1.56 & 1.66 \\
\hline Sdr, \% & 99.4 & 66.5 & 99.8 & 85.1 & 91 & 102 \\
\hline Spd, $1 / \mathrm{mm}^{2}$ & 6.7 & 6.01 & 3.42 & 3.21 & 3.85 & 5.14 \\
\hline Spc, $1 / \mathrm{mm}^{2}$ & 83.9 & 53.1 & 59 & 57.3 & 53.3 & 54.9 \\
\hline Sda, $\mathrm{mm}{ }^{2}$ & 0.08 & 0.10 & 0.09 & 0.10 & 0.11 & 0.07 \\
\hline Sha, $\mathrm{mm}{ }^{2}$ & 0.09 & 0.11 & 0.13 & 0.18 & 0.13 & 0.12 \\
\hline St, $\mu \mathrm{m}$ & 475 & 475 & 704 & 719 & 628 & 505 \\
\hline Sds, $1 / \mathrm{mm}^{2}$ & 78.2 & 119 & 47.6 & 77.1 & 45.6 & 81.6 \\
\hline Ssc, $1 / \mathrm{mm}^{2}$ & 64.1 & 48.2 & 51.9 & 51.4 & 49.1 & 52.6 \\
\hline Spq & 25.9 & 29.2 & 40.3 & 17.2 & 23.6 & 8.45 \\
\hline Svq & 79.3 & 92.9 & 82.5 & 84.5 & 69.3 & 99.6 \\
\hline Smq & 28.1 & 61.7 & 48.4 & 29.8 & 21.3 & 34.1 \\
\hline Sbi & 0.89 & 1.21 & 0.46 & 1.77 & 1.05 & 2.72 \\
\hline & & & & & & \\
\hline
\end{tabular}

\section{Conclusions}

The machining potential of abrasive tools results from the features of their structure, type and properties of abrasives and binders, geometrical parameters of abrasive grains and topography of the active surface. During the grinding process, abrasion of the grain tops occurs and micro- and macrocrumb grains occur, which means that the surface topography of the tool changes mainly. The advantageous stereometric features of the active surface of the grinding wheel can be considered: the persistent and renewable sharpness of the grain tops, in many cases also a large number of micro-crops, and in precise processing - small dispersion of the active blades' radiation.

Different signals extracted from the implemented process or research on the properties of tools can be used to evaluate the processing potential. There are many parameters known to evaluate the geometric features of a surface. Parameters useful for the evaluation of the surface after treatment do not have the information content sufficient to accurately assess the grinding wheel surface condition and predict the machining results.

The aim of the authors was to develop a methodology to assess the active surface condition of abrasive tools using new parameters with better information usefulness, fulfilling the condition of complementarity and easy to interpret relations between parameter values and specific surface features of tools - to help determine possible adjustments to the grinding wheel surface process and predict their durability.

One of the new parameters is the index of the height and variability of the height (sharpness) of the grain tops, referring to the surface (3D). This index integrates the influence of the height and the sharpness of the corners, and its analysis in relation to individual points of the assessed surface allows to determine the form of wear and to conclude about the tooling potential of the tool.

The use of the indicated method of replicas makes it possible to assess the condition of the grinding wheel without dismantling it from the machine spindle. 


\section{REFERENCES}

1. Brandt A. "Noise and Vibration Analysis: Signal Analysis and Experimental Procedures". Chichester, UK: John Wiley \& Sons, 2011.

2. Gawlik J., Niemczewska-Wójcik M., Krajewska J., Sokhan S.V., Paščenko E.A., Žuk T.S. "The influence of tool composite's structure during process of diamond grinding of ceramic materials". Management and Production Engineering Review. 5, 4 (2014): pp. 9-17.

3. Hecke R.L., Liang S.Y. "Predictive modeling of surface roughness in grinding". International Journal of Machine Tools \& Manufacture. 43 (2003): pp. 755-761.

4. Kacalak W., Lipiński D., Rypina Ł., Szafraniec F., Tandecka K., Bałasz B. "Performance evaluation of the grinding wheel with aggregates of grains in grinding of Ti-6Al-4V titanium alloy". International Journal of Advanced Manufacturing Technology. (2017): DOI: 10.1007/s00170-017-0905-x.

5. Kacalak W., Szafraniec F., Tomkowski R., Lipiński D., Łukianowicz Cz. „Metodyka oceny zdolności klasyfikacyjnej parametrów charakteryzujących cechy stereometryczne nierówności powierzchni”. Pomiary Automatyka Kontrola. 57 (2011): pp. 542-546.

6. Kacalak W., Kasprzyk M., Krzyżyński T., Lewkowicz R., Ściegienka R. "Methods and Characteristics of Micro-Cutting and Micro-Smoothing Processes in a Vacuum". Proc. Third International Conference on "Metal Cutting and High Speed Machining", Metz, France, II (2001): pp. 189-192.

7. Kacalak W., Lewkowicz R., Bałasz B., Zawadka W. "Optimierung der Schleifprozesse schwer zerspanbarer Werkstoffe bei niedrigen Temperaturen und im Vakuum". VD Berichte 1276, Bearbeitung neuer Werkstoffe - 2nd International Conference On Machining Of Advanced Materials. Düsseldorf: VDI Verlag, 1996, pp. 617-640.

8. Kacalak W., Lewkowicz R., Dziura Z. "Methoden und Probleme bei der Präzisionsbearbeitung kleiner Keramikformstücke". VD Berichte 1276, Bearbeitung neuer Werkstoffe - 2nd International Conference On Machining Of Advanced Materials. Düsseldorf: VDI Verlag, 1996, pp. 53-74.

9. Kacalak W., Lipiński D. "Adaptive system of quality supervising in technological processes". Advances in Manufacturing Science and Technology. 28, 2 (2004): pp. 7-16.

10. Kacalak W., Różański R., Lipiński D. "Evaluation of classification ability of the parameters characterizing stereometric properties of technical surfaces". Journal of Machine Engineering. 16, 2 (2016): pp. 86-94.

11. Kacalak W., Szafraniec F., Lipiński D. „Probabilistyczna analiza aktywności ziaren na czynnej powierzchni ściernicy”. Mechanik. 8-9 (2014): pp. 176-184.

12. Kacalak W., Szafraniec F., Tandecka K. „Metodyka modelowania powierzchni czynnej narzędzi ściernych z uwzględnieniem korelacji przestrzennego rozmieszczenia ich wierzchołków dla określonych ściernic rzeczywistych". Mechanik. 8-9 (2014): pp. 255-262.

13. Kacalak W., Bałasz B., Tomkowski R., Lipiński D., Królikowski T., Szafraniec F., Tandecka K., Rypina Ł. „Problemy naukowe i kierunki rozwoju procesów mikroobróbki ściernej”. Mechanik. 8-9 (2014): pp. 157-170.

14. Kacalak W., Szafraniec F. „Modelowanie obciążeń ziaren aktywnych i sił w procesie szlifowania”. Mechanik. 8-9 (2013).

15. Kacalak W., Tandecka K., Lipiński D., Szafraniec F., Rypina Ł., Socha E. „Ocena zużycia promieniowego nowych narzędzi do szlifowania zawierających mikroagregaty ścierne z wykorzystaniem metody skanowania przestrzennego". Mechanik. 8-9 (2016): pp. 1174-1175, DOI 10.17814/mechanik.2016.8-9.304.

16. Kacalak W., Tandecka K., Mathia T.G. "A method and new parameters for assessing the active surface topography of diamond abrasive films". Journal of Machine Engineering. 16, 4 (2016): pp. 95-108.

17. Kacalak W., Tandecka K., Rypina Ł., Lipiński D., Szafraniec F., Socha E. „Modelowanie i analiza procesów mikroskrawania agregatami ściernymi". Mechanik. 8-9 (2016): pp. 1172-1173.

18. Kacalak W., Tandecka K., Rypina $Ł$. "Evaluation of micromachining processes using data in the format and geometric characteristics of micro-chips". Journal of Machine Engineering. 15, 4 (2015): pp. 59-68

19. Kacalak W., Tandecka K., Sempruch R. „Badania modelowe procesu mikroskrawania”. Mechanik. 8-9 (2013).

20. Kacalak W. „Teoretyczne podstawy minimalizacji energii właściwej w procesach obróbki ściernej”. XX Naukowa Szkoła Obróbki Ściernej, Poznań 1997, pp. 77-81.
21. Kaiser J.F. "On a simple algorithm to calculate the 'energy' of a signal. Int. Conf. on Acoustics, Speech, and Signal Process, 1990, vol. 1, pp. 381-384.

22. Kapłonek W., Łukianowicz C., Nadolny K. "Methodology of the assessment of the abrasive tool's active surface using laser scatterometry". Transactions of the Canadian Society for Mechanical Engineering. 36, 1 (2012): pp. 49-66.

23. Kapłonek W., Musiał W. „Detekcja $i$ analiza zalepień powierzchni czynnej ściernic diamentowych z wykorzystaniem skaterometrii laserowej oraz komputerowej analizy obrazu. Podstawy i technika obróbki ściernej". Monografia. Łódź: Wydział Mechaniczny Politechniki Łódzkiej, 2010, pp. 205-216.

24. Lipiński D., Kacalak W., Tomkowski R. "Methodology of evaluation of abrasive tool wear with the use of laser scanning microscopy". SCANNING. (2013): DOI: 0.1002/sca.21088.

25. Lipiński D., Kacalak W., Tomkowski R. "Application of the laser scanning microscopy to evaluation of abrasive tool wear". Journal of Machine Engineering. 12, 4 (2012): pp. 99-105.

26. Lipinski D., Majewski M. "Interactive Hybrid Systems for Monitoring and Optimization of Micro- and Nano-machining Processes". ICONIP 2013, Daegu, Korea. Lecture Notes in Computer Science. Vol. 8227 - Neural Information Processing. Springer 2013, pp. 360-367.

27. Lipinski D., Majewski M. "System for Monitoring and Optimization of Micro- and Nano-Machining Processes Using Intelligent Voice and Visual Communication". IDEAL 2013, Hefei, China. Lecture Notes in Computer Science. Vol. $8206-$ Intelligent Data Engineering and Automated Learning. Springer 2013, pp. 16-23.

28. Lipiński D., Kacalak W. "Metrological aspects of abrasive tool active surface topography evaluation". Metrology and Measurements Systems. 23, 4 (2016): pp. 567-578, DOI 10.1515/mms-2016-0043.

29. Lipiński D., Kacalak W. „Zastosowanie metod analizy obrazu do oceny powierzchni czynnej narzędzia ściernego". Mechanik. 89 (2016): pp. 1152-1153, DOI 10.17814 /mechanik.2016.89.293.

30. Lubimow W., Oczoś K.E., Łabudzki R.K. „Klasyfikacja struktur geometrycznych powierzchni (SGP)”. Obróbka ścierna, podstawy i technika. Zbiór prac XIII Naukowej Szkoły Obróbki Ściernej. 2000.

31. Maragos P., Kaiser J.F., Quatieri T.F. "On amplitude and frequency demodulation using energy operators". IEEE Transactions on Signal Processing.41, 4 (1993): pp. 15321550.

32. Mathia T.G., Pawlus P., Wieczorowski M. "Recent trends in surface metrology”. Wear. 271, 3-4 (2011): pp. 494-508.

33. Pawlus P. „Topografia powierzchni - pomiar, analiza, oddziaływanie”. Rzeszów: Oficyna Wydawnicza Politechniki Rzeszowskiej, 2005, pp. 165-168.

34. Stachowiak G.W., Posiadlo P. "Classification of tribological surfaces". Tribology International, 2004.

35. Stępień $P$. "Applied a probabilistic model of the grinding process". Mathematical Modelling. 33 (2009): pp. 3863-3884.

36. Tomkowski R., Kacalak W., Lipiński D. "Evaluation of the surface topography after precision machining". Journal of Machine Engineering. 12, 4 (2012): pp. 71-80.

37. Tomkowski R., Kacalak W., Lipiński D. "Methodology of evaluation of extra smooth surfaces with the use of new evaluation parameters". Proceedings of the International Conference on Surface Metrology, France 2012, pp. 64-71.

38. Tönshoff H.K., Friemuth T., Becker J.C. "Process monitoring in grinding". CIRP Annals - Manufacturing Technology. 51, 2 (2002): pp. 551-571.

39. Wegener K., Hoffmeister H.W., Karpuschewski B., Kuster F., Hahmann W.C., Rabiey M. "Conditioning and monitoring of grinding wheels". CIRP Annals - Manufacturing Technology. 60, 2 (2011): pp. 757-777.

Translation of scientific articles, their computer composition and publishing them on the website www.mechanik.media.pl by original articles in Polish is a task financed from the funds of the Ministry of Science and Higher Education designated for dissemination of science.

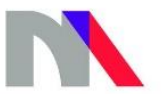
and Higher Education Republic of Poland 